\title{
THE EFFECT OF CORPORATE SOCIAL RESPONSIBILITY DISCLOSURE AND CORPORATE GOVERNANCE ON TAX AVOIDANCE \\ (Empirical Study of Property, Real Estate, and Building Construction Companies that Go Public in Kompas 100 Index 2013-2018)
}

\author{
Anna Christin Silaban \\ Universitas Mercu Buana, \\ Jakarta, Indonesia
}

\author{
Hasian Purba \\ Universitas Mercu Buana, \\ Jakarta, Indonesia
}

\begin{abstract}
The purpose of this study is to examine the effect of corporate social responsibility disclosure, independent board of commissioners, audit committee, and audit quality on tax avoidance. This type of research used in this study is casual associative research (causal associative research). The population in this study are property, real estate, and building construction companies which are included in the Kompas 100 index which are listed on the Indonesia Stock Exchange (IDX) during 2013-2018. Sample selection with purposive sampling method. The analytical method used to test hypotheses is the multiple regression test. The results showed that: 1) Variable disclosure of Corporate Social Responsibility affects tax avoidance in a negative direction, 2) Variables independent board of commissioners influence the tax avoidance in a negative direction; 3) The audit committee variable has no effect on tax avoidance; and 4) Variable audit quality does not affect tax avoidance.
\end{abstract}

KEYWORDS:Corporate Social Responsibility, Corporate Governance, Tax Avoidance

\section{INTRODUCTION}

Tax is the biggest source of state revenue. The tax collected by the State functions as a source of funds intended for financing government expenditure and functions as a tool to regulate and implement policies in the social and economic fields and is used for the greatest prosperity of the people. Therefore, corporate and individual taxpayers are expected to be obedient in carrying out their tax obligations voluntarily and in compliance with tax regulations. Non-compliance of taxpayers can cause disruption of State finances. One way of non-compliance is done by way of tax avoidance, which is legal tax avoidance that does not violate tax regulations by taxpayers by reducing the amount of tax owed by looking for weaknesses (Hutagoal, 2007 in Dewi \& Jati, 2014).

In an effort to reduce the tax burden the management can do a variety of ways such as tax avoidance (tax avoidance). Tax avoidance (tax avoidance) is an aggressive tax strategy carried out by companies in order to minimize the tax burden, so this activity raises risks for companies, including fines and bad reputation of the company in the eyes of the public (Ayu \& Lulus, 2012). The tax avoidance that is done is said to be not in conflict with the taxation regulations because it is considered that practices related to tax avoidance are more utilizing loopholes in the taxation laws that will affect state revenue in the tax sector (Mangoting, 1999 in Dewi \& Teak, 2014). However, the practice of tax avoidance cannot always be implemented because taxpayers do not always avoid all elements or facts imposed in taxation (Dewi \& Jati, 2014).

According to Fitri \& Tridahus (2015), the issue of tax avoidance is a complex and unique problem. On the one hand it is permissible but on the other hand avoidance of unwanted taxes. In Indonesia, various regulations have been made to prevent tax avoidance. One of them is related to transfer pricing, which is about the principle of fairness and custom in transactions between taxpayers and parties who have a special relationship (Perdirjen No. PER-43/PJ/2010, 2010).

Cases involving tax avoidance that have been carried out by well-known companies such as Apple Inc. (2012) which have hidden income money of US \$ 11 billion in countries that have received tax breaks include Virginia Island, Ireland and Luxembourg. So the tax paid is small. Starbuck (2012) who made financial statements as if they were at a loss by paying 
royalties on designs, recipes and logos to branches in the Netherlands. Paying debt interest is very high, where the debt was apparently used for coffee shop expansion in other countries. Buy raw materials from branches in Switzerland. Although shipping goods directly from the producer country and does not enter Switzerland. Internet search engine company in the United States (2011) The company posted revenue in the UK of 398 million pounds in 2011 , but only paid a tax of 6 million pounds. The profits from the British branch company were transferred to branches in Ireland, the Netherlands and Bermuda. Bermuda country is a tax haven country that does not collect corporate income tax. And other cases that make state income in the taxation sector decrease (merdeka.com).

Companies that behave tax avoidance are considered to be socially irresponsible. Corporate social responsibility or Corporate Social Responsibility (CSR) is called a sustainable business commitment that contributes to the economy through collaboration with interested parties and influences the surrounding environment and the general public to improve the quality of facilities and the survival of the local community and in general by useful ways, both for the business itself and for the wider community or for development (World Bank Group in Sutedi, 2015). Companies that implement Corporate Social Responsibility activities make an effort to obtain large profits by not eliminating social responsibility to the environment or other parties affected by the activities of the entity.

Some Corporate Social Responsibility items are expenses that can be charged as expenses (deductible expenses), for example waste treatment costs, internship fees, scholarships, and training, donations in the context of national disaster management, donations of educational facilities and others (Femitasari, 2014). So it is undeniable that many companies carry out Corporate Social Responsibility activities as a form so that taxable income is reduced by carrying out Corporate Social Responsibility which can be charged as a cost to reduce gross income.

The relationship of CSR with tax avoidance can be explained that CSR is a form of corporate responsibility to all stakeholders. Tax is a form of corporate social responsibility to stakeholders through the government. Thus, companies involved in tax avoidance are companies that are not socially responsible (Lanis and Richardson, 2012), so the company's decision to practice tax avoidance is also influenced by the decision to carry out CSR activities (Hidayat et al., 2016).

Hoi et al., (2013) examined Public United State companies in 2003-2009. As a result, companies with irresponsible CSR disclosure companies aggressively engage in tax avoidance practices. Research conducted by Dharma and Noviari (2017) aims to examine and provide empirical evidence of the influence of corporate social responsibility (CSR) and capital intensity on tax avoidance. The results show that companies carrying out higher CSR activities do not practice tax avoidance as a form of socially responsible action.
An entity that carries out its Corporate Social Responsibility activities properly, is inseparable from a company that has good responsibilities in managing its company. Corporate governance activity, also called CG, is a corporate governance. An entity has governance to control and determine the direction of company performance (Haruman, 2008 in Annisa and Kurniasih, 2012).

Corporate governance is a system or mechanism that regulates and controls companies to create added value for stockholders. Corporate governance began to be the subject of discussion in Indonesia in 1998 when the country hit a crisis. Many parties believe that the duration of improvement in the economy at that time was caused by the weak implementation of corporate governance in an entity or company. Finally, the government and investors really pay special attention to corporate governance. The implementation of corporate governance is expected to influence the entity to behave professionally, transparently and efficiently as well as optimize the company's managerial function in each General Meeting of Shareholders (GMS) (Irawan and Aria, 2012).

Good corporate governance can affect tax avoidance or tax avoidance. This was proven empirically by previous researchers such as the research conducted by Syeldila \& Niki (2015), the results of the study showed that the proportion of independent commissioners, audit quality, and audit committee had a negative and significant effect on tax avoidance. According to Arry (2017) in the Influence of Independent Commissioners, Audit Committees, and Audit Quality Against Tax Avoidance, the results of the study show that independent commissioners and audit quality have a positive effect on tax avoidance, the audit committee has no significant effect on tax avoidance.

Researchers are motivated to conduct research on Property, Real Estate, and Building Construction Companies, because Property, Real Estate and Building Construction Companies play an important role in the field of economy and development in Indonesia. This sector is also one indicator to assess a country's economic development.

Based on this background, this study aims to examine the effect of corporate social responsibility disclosure, independent board of commissioners, audit committees, and audit quality on tax avoidance.

\section{LITERATURE REVIEW Agency Theory}

Jensen and Meckling (1976) state that an agency relationship is a contract between a manager (agent) and an investor (principal). There is a conflict of interest between the owner and agent because the possibility of the agent acting is not in accordance with the interests of the principal, thereby triggering agency costs. Conflict in agency theory is usually caused by decision makers who do not participate in taking risks as a result of decision making mistakes. According to decision makers, the risk should be borne by the shareholders. This is what causes the 
asynchronous between the decision maker (manager) with the shareholders. Conflicts between shareholders and company management can be minimized in a way, managers must run the company in accordance with the interests of shareholders as well as in making decisions by managers must be adjusted to the interests of shareholders (Wahyuni, 2013).

\section{Stakeholders Theory}

According to Clarkson (1995) in Fauzan (2013), stakeholders are divided into two groups, namely primary and secondary. Primary stakeholders are groups of stakeholders who do not take part or participate in the operations of a company. Secondary stakeholders are groups of stakeholders who influence and are influenced by the company, but are not involved and are not so important for the survival of the company.

Stakeholder theory is a theory which states that a company is an entity that not only operates for its own interests, but must provide benefits to all its stakeholders, because the survival of a company is supported by stakeholders (Ghazali and Chariri, 2007). Shareholders, creditors, consumers, suppliers, the government, the public, analysts, and other parties are stakeholder groups that are considered by the company to disclose or not reveal information in the company's financial statements. All stakeholders have the right to obtain information about company activities.

\section{Corporate Social Responsibility}

Coporate Social Responsibility (CSR) is an action or concept carried out by the company (according to the company's ability) as a form of their responsibility towards the social or the environment around the company (Rachmad, et al., 2011). Corporate Social Responsibility involves all relationships that occur in the company with all stakeholders including customers, or customers, employees, communities, owners or investors, government, and even the community. If a company manages the company's CSR well, then the company will get significant benefits and benefits in the form of a company's reputation, namely, in terms of employee recruitment, motivation and reference as well as suggestions for building and maintaining cooperation. CSR disclosure is done using the CSDI approach. This approach uses a dichotomous approach, where each item of social responsibility in the research instrument is given a value of 1 if disclosed, and a value of 0 if not disclosed (Haniffa et al., 2005 in Sayekti and Wondabio, 2007). Then the score of each item is added together to get the overall score for each company.
The CSDI calculation formula is as follows (Haniffa et al., 2005 in Sayekti and Wondabio, 2007): $\operatorname{CSDIj}=\frac{\Sigma \mathrm{Xij}}{\mathrm{nj}}$

Information :

$\mathrm{CSDIj}=$ Corporate Corporate Disclosure Index $\mathrm{j}$

$\mathrm{Nj} \quad=$ number of items to disclose, $\mathrm{nj}=79$

$\mathrm{Xij}=$ the number of known items scores 1 if the item is unknown, 0 if the item is not known disclosure.

\section{Good Corporate Governance (GCG)}

According to Keasy, Corporate governance is a structure, process, culture and system for creating successful operational conditions for an organization (Sunarto in Syukri and Chenny, 2018). Koesnohadi (in Syukri and Chenny, 2018) said that "Good Corporate Governance is a relationship between stakeholders that is used to determine and control the strategic direction and performance of the organization".

According to Tangkilisan (2003, in Angrum, 2016) good corporate governance (GCG) is a system and structure for managing companies with the aim of increasing company value and allocating it to various interested parties such as creditors, suppliers, business associations, consumers, workers, government and wide community. The same thing also expressed by Sutedi (2011) GCG by definition is a system that regulates and controls companies to create added value for all shareholders (stakeholders). GCG can only be created if there is a balance between the interests of all parties with the interests of the company to achieve company goals (Khairandy and Malik, 2007 in Angrum, 2016).

From the above understanding it can be concluded that Good Corporate Governance is a system of corporate governance in order to be better and can increase Company Value by promoting fairness for all stakeholders, transparency regarding the condition of the company as part of the external environment. (Haris, 2008 in Syukri and Chenny, 2018)

The measurement of corporate governance in this study uses the following variables:

a. Independent Board of Commissioners

According to Puspitasari and Ernawati (2010 in Syukri and Chenny, 2018) independent commissioners are members of the board of commissioners who have no financial, management, share ownership and / or family relationship with other members of the board of commissioners, directors and / or controlling shareholders or other relationships who is able to act independently. The board of commissioners plays an important role in corporate governance, because company law concerns the legal affairs and responsibilities of the company to the board of commissioners.

In a company, the board of commissioners represents the main internal mechanism in carrying out the control function of the principal and oversees the opportunist behavior of management. The board of commissioners also acts as a representative of shareholders whose function is to 
exercise control and provide advice to directors to run GCG. The dual board (two-tier) system is a system used by companies in their internal organizational structures, better known as boards of commissioners and boards of directors.

The proportion of independent commissioners in this study was calculated using the ratio of independent commissioners divided by the total number of all boards of commissioners.

b. Audit Committee

The audit committee is the committee responsible for overseeing external audits and is the main contact between the auditor and the company (Dewi \& Jati, 2014). The existence of an audit committee within a company is expected to be able to provide insight on matters relating to financial policies, accounting, and internal control of a company. In this study the audit committee will be measured using a ratio that is the number of audit committees outside the independent commissioners divided by the number of audit committees in the company.

c. Audit quality

Audit quality is any possibility that can occur when the auditor audits the client's financial statements and finds violations or errors that occur and report them in the audited financial statements (Dewi \& Jati, 2014). Transparency towards shareholders can be achieved by reporting matters related to taxation in the capital market and the meeting of shareholders. Increased transparency towards shareholders in tax matters is increasingly being demanded by public authorities (Sartori, 2010). Because of the assumption of the implications of aggressive tax behavior, their companies take an aggressive position in tax matters and would prevent such actions if they were a year earlier. Therefore, audit quality is measured using a dummy variable of value 1 if the financial statement audit is carried out by The Big Four Public Accounting Firm (KAP) namely Price Water House Cooper-PWC, Deloitte Touche Tohmatsu, KPMG, and Ernst \& Young-E \& Y, and is 0 if the financial statement audit is not carried out by The Big Four Public Accountant Firm (KAP).

\section{Tax avoidance}

Tax Avoidane is a business transaction scheme aimed at minimizing the tax burden by utilizing the weaknesses (loophole) of a country's taxation provisions. According to Lim (2011) defines tax avoidance as tax savings that arise by utilizing tax provisions that are done legally to minimize tax obligations.

Tax avoidance (tax avoidance) is an effort to avoid tax that is done legally and safely for taxpayers because it does not conflict with taxation provisions, where the methods and techniques used tend to exploit the weaknesses (gray areas) contained in the laws and regulations taxation itself, to reduce the amount of tax owed (Pohan, 2013).
According to Dyreng et al. (2010) this variable is calculated using the cash effective tax rate (CETR), which is the payment of income tax divided by profit before tax.

\section{Previous Research Review}

Previous research that can support this research is Christopher, et al. (2015) in his study entitled "Corporate governance, incentives, and tax avoidance" provides empirical evidence that a positive relationship between board independence and financial sophistication is for a low level of tax avoidance, but a negative relationship for a high level of tax avoidance. These results indicate that these governance attributes have a stronger relationship with more extreme levels of tax avoidance, which are more likely to be symptoms of over-investment and underinvestment by managers.

Rahmawati, et al (2016) in her study entitled "The Effect of Disclosure of Corporate Social Responsibility and Corporate Governance on Tax Avoidance (Studies in Manufacturing Companies Listed on the Indonesia Stock Exchange for the 20122014 Period)" provides evidence that the proportion of CSR and independent commissioners has a positive and significant effect , managerial ownership, institutional ownership, has a negative and significant effect on tax avoidance, while the audit committee and the quality of external auditors have no significant effect on tax avoidance.

Arry (2017) in his research entitled "The Effect of Independent Commissioners, Audit Committees, and Audit Quality on Tax Avoidance" provides empirical evidence that independent commissioners and audit quality have a positive effect on tax avoidance, audit committees do not significantly influence tax avoidance. Simultaneously independent commissioners, audit committees and audit quality significantly influence tax avoidance

Fitria (2018) in her research entitled "The Effect of Institutional Ownership, Independent Commissioners, Executive Character and Size on Tax Avoidance (Empirical Study of Trade Sector Issuers Registered on the Indonesia Stock Exchange in 20142017)" provides evidence that institutional ownership, Independent Commissioners, characteristics the executive has no significant effect on tax avoidance. While the size of the company has a significant effect on tax avoidance.

Ningrum et al. (2018) in his research entitled "The Effect of Corporate Social Responsibility Disclosure on Tax Avoidance with Gender as a Moderation Variable (Empirical Study on Manufacturing Companies Listed on the Indonesia Stock Exchange in 2016)". The results of this study indicate that CSR disclosure has a negative effect on tax avoidance. Gender (the proportion of women on 
company boards) has strengthened the effect of CSR disclosure on tax avoidance practices.
Based on the theoretical basis and some previous research, the framework in this study can be shown by the following picture:

\section{Theoretical Thought Framework}

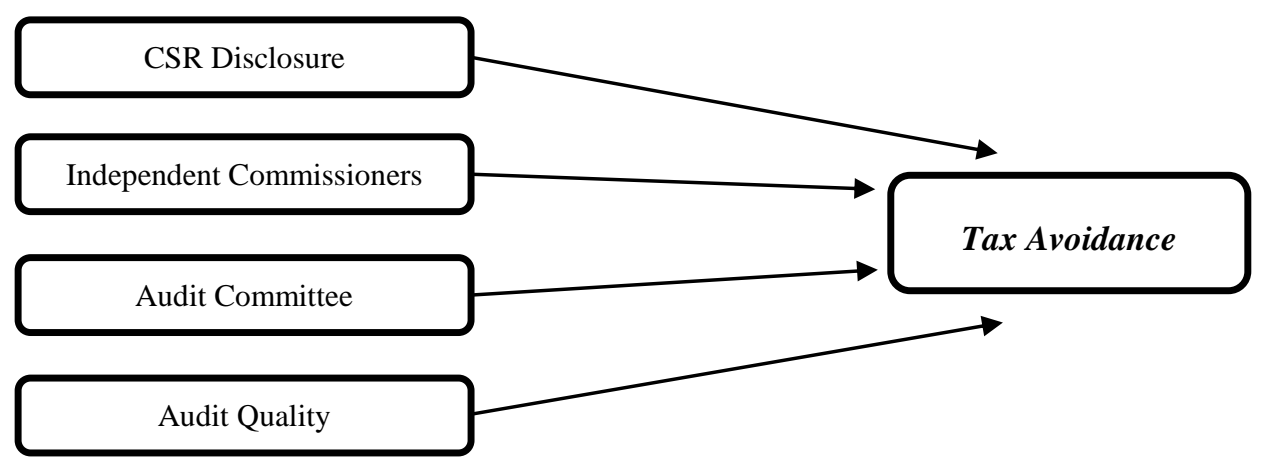

Figure 1.1 Research Model

Research Hypothesis

From the above thought framework, the researcher draws a hypothesis as follows:

$\mathrm{Ha}_{1}=$ CSR disclosure has a negative effect on Tax Avoidance

$\mathrm{Ha}_{2}=$ Independent Board of Commissioners has a negative effect on Tax Avoidance

$\mathrm{Ha}_{3}=$ Audit Committee has a negative effect on Tax Avoidance

$\mathrm{Ha}_{4}=$ Audit Quality has a negative effect on Tax Avoidance

\section{RESEARCH METHODOLOGY}

Types of research

This type of research used in this study is casual associative research (causal associative research). According to Sanusi (2011), associative-causal research is research that looks for relationships between two or more variables. The purpose of associative research is to look for relationships between one variable and another.

\section{Operational Definition and Variable} Measurement

The variables used in this study consisted of the dependent variable and the independent variable. Operational research variables can be summarized in table 1.1 . 
Table 1.1 Operationalization of Variables

\begin{tabular}{|c|c|c|c|}
\hline Variable Type & Operational definition & Measurement & Scale \\
\hline \multicolumn{4}{|l|}{ Dependent } \\
\hline Tax Avoidance & $\begin{array}{l}\text { Tax avoidance efforts are carried out legally and } \\
\text { safely for taxpayers because they do not conflict } \\
\text { with taxation provisions, where the methods and } \\
\text { techniques used tend to exploit the weaknesses } \\
\text { (gray area) contained in the laws and tax } \\
\text { regulations themselves, to reduce the amount tax } \\
\text { owed }\end{array}$ & $\begin{array}{l}\text { Cash Effective Tax } \\
\text { Rate (CETR) }\end{array}$ & Rasio \\
\hline \multicolumn{4}{|l|}{ Independent } \\
\hline $\begin{array}{l}\text { CSR } \\
\text { Disclosure }\end{array}$ & $\begin{array}{l}\text { An action or concept carried out by the company } \\
\text { (according to the company's ability) as a form of } \\
\text { their responsibility towards the social or the } \\
\text { environment around the company (Rachmad, et } \\
\text { al., 2011) }\end{array}$ & $\begin{array}{l}\text { Corporate Social } \\
\text { Disclosure Index }\end{array}$ & Rasio \\
\hline $\begin{array}{l}\text { Independent } \\
\text { Board of } \\
\text { Commissioner } \\
\text { S }\end{array}$ & $\begin{array}{l}\text { Members of the board of commissioners who do } \\
\text { not have financial, management, share } \\
\text { ownership and / or family relations with the } \\
\text { controlling shareholder, members of the board of } \\
\text { commissioners and / or directors (Bank } \\
\text { Indonesia Regulation number } \\
11 / 33 \text { / PBI / 2009) }\end{array}$ & $\begin{array}{l}\text { The number of } \\
\text { independent } \\
\text { directors is divided } \\
\text { by the total } \\
\text { number of the } \\
\text { board of } \\
\text { commissioners }\end{array}$ & Rasio \\
\hline $\begin{array}{l}\text { Audit } \\
\text { Committee }\end{array}$ & $\begin{array}{l}\text { The committee responsible for overseeing } \\
\text { external audits and is the main contact between } \\
\text { the auditor and the company (Dewi \& Jati, 2014) }\end{array}$ & $\begin{array}{c}\text { The number of } \\
\text { Audit Committees } \\
\text { outside the } \\
\text { independent } \\
\text { commissioners is } \\
\text { divided by the } \\
\text { number of Audit } \\
\text { Committees in the } \\
\text { company }\end{array}$ & Rasio \\
\hline Audit quality & $\begin{array}{l}\text { All possibilities that can occur when the auditor } \\
\text { audits the client's financial statements and finds } \\
\text { violations or errors that occur and report it in } \\
\text { the audited financial statements (Dewi \& Jati, } \\
2014 \text { ) }\end{array}$ & $\begin{array}{c}\text { Values } 1 \text { when } \\
\text { financial reporting } \\
\text { audits are } \\
\text { performed by KAP } \\
\text { The Big Four, and } \\
0 \text { when financial } \\
\text { statements audits } \\
\text { are not performed } \\
\text { by KAP The Big } \\
\text { Four }\end{array}$ & dummy \\
\hline
\end{tabular}

\section{Data Types and Sources}

The data used in conducting this research is secondary data, that is data obtained through intermediaries from both parties and certain media that support this research. The data used in this study are secondary data in the form of financial statements of property companies, real estate, and building construction which are included in the Kompas 100 index listed on the Indonesia Stock Exchange during 2013-2018 obtained from the Indonesia Stock
Exchange website (www.idx.co .id) and the official website of each bank.

\section{Population and Research Samples}

The population in this study are property, real estate, and building construction companies which are included in the Kompas 100 index which are listed on the Indonesia Stock Exchange (IDX) during 20132018. The sample is part of the population used to estimate population characteristics. The sampling 
technique is using purposive sampling technique. According to Widyani (2010) the purposive sampling method is the selection of samples on the basis of the suitability of the characteristics of the sample with the specified sample selection criteria. The sample criteria used in this study are:

1. Property, Real Estate, and Building Construction Companies included in the Kompas 100 index and listed on the Indonesia Stock Exchange (IDX) within 2013-2018.

2. Publish audited financial statements for the period 2013-2018

3. The company did not experience a loss during the study year.

4. Data owned by the company are complete and in accordance with the variables studied.

According to the criteria above, the number of samples used were 13 companies during the 6 periods namely 2013, 2014, 2015, 2016, and 2018. Then the number of samples obtained was 13 companies x 6 periods $=78$ data to be used in this study.

\section{Data collection technique}

Data collection methods in this study are library study methods and documentation methods. Literature study method by studying literature and reviewing various literature literatures such as various journals, articles and other literature books that support this research process. While the documentation method is the process of collecting data by recording documents related to this study.

\section{Analysis Method \\ Descriptive statistics}

Descriptive statistics in this study are used to provide a description of the character of the research variable using a frequency distribution table that shows the mode number, the range of scores and the standard of division

\section{Classic assumption test}

This research was conducted with a simple regression analysis. The use of simple regression analysis must be free from testing classic assumptions. For this reason, before a simple regression analysis is required, classical assumptions must be tested first. Testing classic assumptions is done using normality test, multicollinearity test, heterokedasticity test and autocorrelation test.

\section{Hypothesis testing}

In this study the authors used four independent variables and one dependent variable. The analytical method used to test hypotheses is the multiple regression method, which is regression used to find out how much influence the independent variable has on the dependent variable. Regression analysis using SPSS software version 25 . The regression equation is as follows: $Y=\alpha+\beta_{1} X_{1}+\beta_{2} X_{2}+\beta_{3} X_{3}+\beta_{4} X_{4}+\varepsilon_{1}$

Where :

$\begin{aligned} \mathrm{Y}= & \text { Tax Avoidance } \\ \alpha= & \text { constant or price of } \mathrm{Y} \text { if } \mathrm{X}=0 \\ \beta= & \text { number or direction of the regression } \\ & \text { coefficient, which indicates the number of } \\ & \text { increase or decrease in the dependent variable } \\ & \text { based on the independent variable } \\ \mathrm{X}_{1}= & \text { CSR Disclosure } \\ \mathrm{X}_{2}= & \text { Independent Board of Commissioners } \\ \mathrm{X}_{3}= & \text { Audit Committee } \\ \mathrm{X}_{4}= & \text { Audit quality } \\ \varepsilon= & \text { error } \\ \varepsilon= & \text { In this study, the significance level }(\alpha) \text { of } 0.05 \text { or }\end{aligned}$ $5 \%$ was used. To test whether the proposed hypothesis is accepted or rejected, a test of the research variables is tested by simultaneously testing the simultaneous significance test ( $\mathrm{F}$ statistic test), which intends to explain the effect of the independent variable on the dependent variable. Meanwhile, to test each variable partially, it is carried out by means of an individual parameter significance test (statistical t test) which aims to find out whether the independent variable influences the dependent variable, and which of the dominant variables influences the dependent variable.

\section{RESEARCH RESULTS AND DISCUSSION \\ Research Data Description}

Descriptive statistical results about the research variables are presented in table 1.2. From this table we can find information about the average, maximum value, minimum value and standard deviation.

Table 1.2 Descriptive Statistics Results

\begin{tabular}{|l|c|c|c|c|}
\hline \multicolumn{1}{|c|}{ Variabel } & Min & Max & Mean & $\begin{array}{c}\text { Std. } \\
\text { Deviation }\end{array}$ \\
\hline CSR Disclosure & 0,15 & 0,94 & 0,47 & 0,237 \\
\hline $\begin{array}{l}\text { Independent of } \\
\text { Commissioners }\end{array}$ & 0,20 & 0,75 & 0,41 & 0,116 \\
\hline Audit Committee & 0,33 & 1,00 & 0,65 & 0,122 \\
\hline Audit quality & 0,00 & 1,00 & 0,23 & 0,424 \\
\hline Tax Avoidance & 0,00 & 0,49 & 0,15 & 0,145 \\
\hline
\end{tabular}

Source: Data processed (2019) 
Based on table 1.2 above, it can be presented descriptive statistical results about the research variables as follows: The average value of CSR disclosure variables is $0.47(47 \%)$ with a standard deviation value of 0.237 (23.7), which shows the level of distribution of distribution data. An average of 0.47 $(47 \%)$, this shows that the average index of CSR disclosure variables by companies is relatively low. CSR disclosure variables range from the lowest value of $0.15(15 \%)$ to the highest value of $0.94(94 \%)$.

The independent commissioner variable has an average of $0.41(41 \%)$. This shows that the independent commissioner variable has fulfilled the requirements determined by the Financial Services Authority Regulation No. 33 / POJK.04 / 2014 that the proportion of independent commissioners must be at least $30 \%$ of the total members of the board of commissioners (OJK 2014). The standard deviation value of the independent commissioner variable is 0.116 , this value indicates the magnitude of increase and decrease in the maximum independent commissioner variable that may occur. The lowest amount is $0.20(20 \%)$ and the highest is $0.75(75 \%)$.

The average value of the audit committee variable is $0.65(65 \%)$ with a standard deviation value of 0.122 (23.7), which shows the level of variation in the data distribution. Audit committee variables range from the lowest value of $0.33(33 \%)$ to the highest value of $1.00(100 \%)$.

The audit quality variable has an average value of 0.23 with a standard deviation of 0.424 . This shows that $23 \%$ of the sample company's financial statements were audited by The Big Four Public Accounting Firm (KAP). The standard deviation value of audit quality variables is 0.474 , this value indicates the magnitude of increase and decrease in maximum audit quality variables that may occur. The lowest value is 0 and the highest value is 1 .

The average value of the tax avoidance variable which is proxied by cash effective tax rates (CETR) has an average of 0.15 with a standard deviation of 0.145 which indicates the level of variation in the data distribution. Tax avoidance variable ranges from the lowest value of 0 , the company Sentul City Tbk. up to the highest value of 0.49 , namely the Adhi Karya (Persero) Tbk company.

\section{Test Prerequisite Analysis Normality test}

Thus the overall results of the normality test calculation using the Lilliefors test can be seen in the summary in table 1.3

Table 1.3 Summary of the Normality Test

\begin{tabular}{|c|c|c|c|c|c|c|}
\hline \multirow{2}{*}{ No } & \multirow{2}{*}{ Estimated } & \multirow{2}{*}{$\mathbf{L}$} & $\mathbf{L}$ count & \multicolumn{2}{|c|}{$\mathbf{L}$ Tabel } & \multirow{2}{*}{ Decision } \\
\cline { 5 - 6 } & & & & $\boldsymbol{\alpha}=\mathbf{0 , 0 5}$ & $\boldsymbol{\alpha}=\mathbf{0 . 0 1}$ & \\
\hline 1 & Y on X1 & 78 & $-0,0001$ & 0,1003 & 0,1167 & Normal \\
\hline 2 & Y on X2 & 78 & 0,0182 & 0,1003 & 0,1167 & Normal \\
\hline 3 & Y on X3 & 78 & $-0,0740$ & 0,1003 & 0,1167 & Normal \\
\hline 4 & Y on X4 & 78 & 0,0098 & 0,1003 & 0,1167 & Normal \\
\hline
\end{tabular}

\section{Multicollinearity Test}

The results of the calculation of tolerance according to table 1.4 shows that there are no independent variables that have a tolerance value of less than $10 \%$; all tolerance values are more than $10 \%$; which means there is no correlation between variables. The results of the calculation of the value of the variance inflation factor (VIF) also show the same thing, there are no independent variables that have a VIF value of more than 10; the values of the variance inflation factor (VIF) are all less than 10. The conclusion is that there is no multicollinearity between independent variables in the regression model based on the tolerance value test.

Table 1.4 Multicollinearity Test Results

\begin{tabular}{|l|c|c|}
\hline \multirow{2}{*}{ Variabel } & \multicolumn{2}{c|}{ Collinearity Statistics } \\
\cline { 2 - 3 } & Tolerance & VIF \\
\hline CSR Disclosure & 0,877 & 1,140 \\
\hline Independent of Commissioners & 0,784 & 1,275 \\
\hline Audit Committee & 0,918 & 1,090 \\
\hline Audit quality & 0,803 & 1,245 \\
\hline
\end{tabular}

Source: Data processed (2019)

\section{Autocorrelation Test}

Autocorrelation test is used to determine whether there is a correlation between the error of the intruder in a certain period and the error of the interfering period before. A good regression model is a regression that is free from autocorrelation. Autocorrelation test can be done by Durbin-Watson (DW) testing. The results of the autocorrelation test can be seen in the following table: 
EPRA International Journal of Multidisciplinary Research (IJMR) - Peer Reviewed Journal Volume: 6 | Issue: 1 | January 2020 || Journal DOI: 10.36713/epra2013 || SJIF Impact Factor: 5.614||ISI Value: 1.188

Table 1.5 Autocorrelation test results

\begin{tabular}{|c|c|c|c|c|c|c|c|}
\hline $\begin{array}{c}\text { Mode } \\
\mathbf{l}\end{array}$ & $\mathbf{n}$ & $\mathbf{k}$ & $\mathbf{d l}$ & $\mathbf{d u}$ & $\begin{array}{c}\text { Durbin } \\
\text { Watson }\end{array}$ & $\mathbf{4 - d \boldsymbol { u }}$ & $\mathbf{4 - d \boldsymbol { l }}$ \\
\hline 1 & 78 & 4 & 1,527 & 1,742 & 1,966 & 2,259 & 2,474 \\
\hline
\end{tabular}

Source: Data processed (2019)

Referring to Ghozali (2011), the regression model in this study is free from the autocorrelation

\section{Heteroscedasticity Test} that it is exposed to heterokedasticity. The test results
are: 1) using the Spearman rank test can be seen in the

Detection of heterokedastisitas are: 1) using the Spearman rank test can be seen in the Probability value $>0.05$ means free from following table:

Table 1.6 Heteroscedasticity Test Results

\begin{tabular}{|l|l|l|c|c|c|c|}
\hline \multicolumn{2}{|c|}{} & $\mathrm{X} 1$ & $\mathrm{X} 2$ & $\mathrm{X} 3$ & $\mathrm{X} 4$ \\
\hline $\begin{array}{l}\text { Spearman's } \\
\text { rho }\end{array}$ & \multirow{2}{|l|}{$\begin{array}{l}\text { Correlation } \\
\text { Coefficient }\end{array}$} & $-0,185$ & $-0,324^{* *}$ & 0,210 & $-0,187$ \\
\cline { 2 - 7 } & \multirow{2}{*}{\begin{tabular}{l} 
Sig. (2-tailed) \\
\cline { 2 - 6 }
\end{tabular}} & 0,105 & 0,054 & 0,065 & 0,102 \\
\cline { 2 - 7 } & $\mathrm{N}$ & 78 & 78 & 78 & 78 \\
\hline
\end{tabular}

Spearman rank test results in the table above shows the significance value of each variable of 0.105 , $0.054,0.065$, and 0.102 . Because the significance value of each variable is greater than 0.05 , it can be concluded that the data are free from heterokedasticity. problem because the Durbin Watson values are between du and $4 \mathrm{du}$.

heterokedastisitas. 2) Probability value $<0.05$ means

\section{Regression Analysis Test}

Multiple regression analysis is used to get the regression coefficient which will determine whether the hypothesis made will be accepted or rejected. By using the multiple linear regression method the following results are obtained:

Table 1.7 Results of regression analysis

\begin{tabular}{|c|c|c|c|c|c|c|c|c|}
\hline \multicolumn{2}{|c|}{ Model } & B & $T_{\text {count }}$ & Sig & $\mathbf{T}_{\text {tabel }}$ & $\operatorname{adj} \mathrm{R}^{2}$ & $F_{\text {count }}$ & Sig \\
\hline \multirow{5}{*}{1} & (Constant & 0,478 & & & \multirow{5}{*}{1,666} & \multirow{5}{*}{0,775} & \multirow{5}{*}{67,243} & \multirow{5}{*}{0,000} \\
\hline & $\mathrm{X} 1$ & $-0,542$ & $-15,302$ & 0,000 & & & & \\
\hline & $\mathrm{X} 2$ & $-0,226$ & $-2,947$ & 0,004 & & & & \\
\hline & $\mathrm{X} 3$ & 0,035 & 0,514 & 0,609 & & & & \\
\hline & $\mathrm{X} 4$ & $-0,007$ & $-0,345$ & 0,731 & & & & \\
\hline
\end{tabular}

Based on the results of the regression tests above, an equation can be formed as follows: $\mathrm{Y}=$ $0,478-0,542 \mathrm{X}_{1}-0,226 \mathrm{X}_{2}+0,035 \mathrm{X}_{3}-0,007 \mathrm{X}_{4}+\varepsilon$

\section{Determination Coefficient Test $\left(\mathbf{R}^{2}\right)$}

From the table above it is known that the adjusted $\mathrm{R}$ square value of 0.775 . This means that $77.5 \%$ of tax avoidance can be explained by variations in independent variables namely disclosure of corporate social responsibility, independent board of commissioners, audit committee, and audit quality, the remaining $22.5 \%(100 \%-77.5 \%)$ explained by other causes outside the model.

\section{Simultaneous Significance Test (Statistical Test F)}

From the Anova test or the $\mathrm{F}$ test in table 1.7 above, the calculated $\mathrm{F}$ value is 67.243 with a significance probability that indicates 0,000 . Test probability values are much smaller than $\alpha=0.05$.
This shows that together (simultaneously) tax avoidance can be influenced by disclosure of corporate social responsibility, independent board of commissioners, audit committee, and audit quality.

\section{Hypothesis test \\ Relationship between Corporate Social Responsibility Disclosure and Tax Avoidance}

Based on the calculation results in table 1.7 above, it can be seen that the variable of corporate social responsibility disclosure affects tax avoidance in a negative direction, which can be seen from the comparison between the table and $\mathrm{t}$ count, ie the table is smaller than $t$ count, with a value of 1.666 and $t$ 15.302 and the significance level is less than 0.05 . Thus Ha1 received. 


\section{Relationship of Independent \\ Commissioners with Tax Avoidance}

Based on the calculation results in table 1.7 above it can be seen that the independent commissioner variable influences the tax avoidance in a negative direction, which can be seen from the comparison between ttable and tcount, which is ttable smaller than tcount, with a ttable value of 1.666 and tcount -2.947 and the level the significance is less than 0.05. Thus $\mathrm{Ha} 2$ received.

\section{Relationship of the Audit Committee with Tax Avoidance}

Based on the calculation results in table 1.7 above, it can be seen that the audit committee variable has no effect on tax avoidance in a positive direction, which can be seen from the comparison between ttable and tcount, ie ttable is greater than tcount, with a ttable value of 1.666 and ttest 0.514 and its level of significance greater than 0.05 . Thus $\mathrm{Ha} 3$ was rejected.

\section{Relationship of Audit Quality with Tax Avoidance}

Based on the calculation results in table 1.7 above it can be seen that the audit quality variable does not affect the tax avoidance with a negative direction, which can be seen from the comparison between ttable and tcount, ie ttable is greater than tcount, with a ttable value of 1.666 and tcount -0.345 and the level the significance is greater than 0.05 . Thus Ha4 was rejected.

\section{Discussion \\ Relationship between Corporate Social Responsibility Disclosure and Tax Avoidance}

From the results of the study note that the variable Corporate Social Responsibility Disclosure affects tax avoidance in a negative direction. This means that the higher the company does CSR disclosure, the lower the company does tax avoidance practice. The results of this study support the research conducted by Hoi et al. (2013) which states that companies with CSR activities that are not socially responsible have higher involvement in tax avoidance. The same thing was expressed by Dharma and Noviari (2017), companies with responsible CSR activities are less likely to be involved in tax avoidance activities.

In Indonesia, CSR activities are voluntary or not mandatory for companies. This can be explained in Law No. 40 of 2007 article 1 paragraph 3 of Limited Liability Companies (PT) states that social and environmental responsibility (CSR) is the company's commitment to participate in sustainable economic development in order to improve the quality of life and the environment that is beneficial, both for the company itself, the community local and community in general. Based on this understanding, social and environmental responsibility (CSR) is a commitment or awareness of the company. Companies with voluntary social responsibility (CSR) disclosure or awareness of the company's organs integrate social and environmental attention and transparency into the company's operations and interactions with its stakeholders. If the company does tax avoidance, the company's reputation will be damaged in the eyes of the public or stakeholders. So that the high level of CSR activities tends to be higher the attitude of responsibility of the company is reflected in the attitude of compliance in paying the tax burden that has been set or not avoiding taxes.

The results of this study support the theory of legitimacy which states that companies will get legitimacy from the public by disclosing CSR activities that have been carried out and making tax payments through the government with a predetermined amount. It also supports stakeholder theory where the company is not only responsible for the interests in the company but also responsible for the interests of all its stakeholders. The company must contribute to society through CSR activities and the government through payment of taxes, so the company can be socially responsible to all stakeholders.

\section{Relationship of Independent Commissioners with Tax Avoidance}

From the results of the study note that the independent commissioner variable has a negative effect on tax avoidance. This shows that the more proportion of independent commissioners owned by the company so that tax avoidance can be minimized. The results of this study are in line with research conducted by Rahmawati, et al (2016), and Arry (2017) which states that independent commissioners influence the actions of minimizing corporate tax, this can be explained that the more the number of independent commissioners, the greater the influence to do supervision of management performance. This supervision can reduce agency problems that arise such as the opportunistic attitude of management to bonuses, so that management has an interest in reducing tax payments to maximize bonuses received by management. With greater supervision, management will be careful in making decisions and transparent in running the company so that tax avoidance can be minimized. Actively the independent commissioner can encourage management to comply with applicable tax laws and reduce risks such as low investor confidence.

\section{Relationship of the Audit Committee with Tax Avoidance}

From the results of the study note that the audit committee variable does not affect the tax avoidance with a negative direction. According to IDX and Bapepam-LK, each company listed on the IDX must 
have an audit committee, whose members consist of one independent commissioner as chairman and at least 2 independent external companies as members. The board of commissioners must establish an audit committee of at least three people who are appointed and dismissed and are responsible for the board of commissioners. Audit committees that have few members tend to act more efficiently, but also have weaknesses, namely the lack of member experience. The results of this study support research conducted by Tommy and Maria (2013) and Rahmi (2014) which state that the audit committee has no significant effect on tax avoidance.

\section{Relationship of Audit Quality with Tax Avoidance}

From the results of the study note that audit quality variables affect tax avoidance in a positive direction. This means that the higher audit quality will cause increased tax avoidance. The results of this study are in line with research Rahmawati, et al (2016) which states that audit quality has no effect on tax avoidance. So companies audited by the big four KAP will indeed be more likely to be trusted by the tax authorities because the KAP has a good reputation, has high integrity, but if the company can provide benefits and better welfare to the KAP that has a good reputation, it could be The KAP was cheating to maximize the welfare of KAP, as was the case with Enron in 2004 (Fadhilah, 2014).

\section{CONCLUSIONS}

Based on the results of the analysis conclusions can be drawn as follows: 1) Variable disclosure Corporate Social Responsibility affects the tax avoidance with a negative direction, 2) Variable independent commissioners influence the tax avoidance with a negative direction; 3) The audit committee variable has no effect on tax avoidance; and 4) Variable audit quality does not affect tax avoidance.

\section{LIMITATION}

There are several limitations encountered in this study, including: 1) This study has the potential for researcher subjectivity when doing a checklist of items on corporate social responsibility disclosure; 2) The researcher limits the object of the research company Property, Real Estate, and Building Construction that Go Public in Compass 100 Index.

\section{SUGGESTIONS}

By considering the existing limitations, it is expected that future research will improve the following factors: 1) In subsequent studies, it is hoped that this research can be used as a basis for conducting research again, especially regarding CSR and corporate governance, it should be added to the period of research again. so that it looks different from year to year and you should use companies from other sectors as a comparison of research. In addition it is hoped that other researchers will replace future research variables with other variables outside the variables in this study and provide a more specific meaning to CSR in the company; 2) For investors it is recommended that significant variables such as independent commissioners can be used as additional information in the company; 3) For management, it is better to further improve the performance of the board of commissioners, especially the independent board of commissioners, to further increase their independence so that tax avoidance actions in each company can be avoided among them by increasing the number of independent boards of commissioners that are not affiliated with the company and have more knowledge about corporate taxation and have more high degree of independence. Given the role of the board of commissioners in this study the most dominant influence tax avoidance measures.

\section{REFERENCES}

1. Aprilian Kusuma Ningrum, Eny Suprapti, dan Achmad Syaiful Hidayat Anwar. (2018). Pengaruh Pengungkapan Corporate Social Responsibility Terhadap Tax Avoidance Dengan Gender Sebagai Variabel Moderasi (Studi Empiris pada Perusahaan Manufaktur yang Terdaftar di Bursa Efek Indonesia Tahun 2016). Balance. Vol. XV, No. 1

2. Arry Eksandy. (2017). Pengaruh Komisaris Independen, Komite Audit, Dan Kualitas Audit Terhadap Penghindaran Pajak (Tax Avoidance). Competitive, Vol. 1, No. 1

3. Ayu Annisa Nuralifmida dan Lulus Kurniasih. (2012). Pengaruh Corporate Governance terhadap Tax Avoidance. Jurnal Bisnis dan Manajemen, Vol. 1, No. 1

4. Ауи Rahmawati; Maria Goretti Wi Endang; dan Rosalita Rachma Agusti. (2016). Pengaruh Pengungkapan Corporate Social Responsibility dan Corporate Governance Terhadap Tax Avoidance (Studi Pada Perusahaan Manufaktur Yang Terdaftar Di BEI Periode 2012-2014). Jurnal Perpajakan (JEJAK). Vol. 10, No. 1

5. Christopher S. Armstronga; Jennifer $L$. Blouina; Alan D. Jagolinzerb; and David F. Larcker. (2015). Corporate governance, incentives, and tax avoidance. Journal of Accounting and Economics. Vol. 60, No. 1

6. Chun-Keung Hoi; Qiang Wu; and Hao Zhang. (2013). Is Corporate Social Responsibility (CSR) Associated with Tax Avoidance? Evidence from Irresponsible CSR Activities. The Accounting Review. Vol. 88, No. 6 
7. Fitri Damayanti dan Tridahus Susanto. (2015). Pengaruh Komite Audit, Kualitas Audit, Kepemilikan Institusional, Risiko Perusahaan dan Return On Assets Terhadap Tax Avoidance. E S E N S I Jurnal Bisnis dan Manajemen. Vol. 5, No. 2

8. Ghozali, I. (2013). Aplikasi Analisis Multivariate dengan Program IBM SPSS 22. Semarang: Badan Penerbit Universitas Diponegoro.

9. Ghozali, Imam dan Chariri, Anis. (2007). Teori Akuntansi. Badan Penerbit Universitas Diponegoro Semarang.

10. Giawan Nur Fitria. (2018). Pengaruh Kepemilikan Institusional, Komisaris Independen, Karakter Eksekutif dan Size Terhadap Tax Avoidance (Study Empiris Pada Emiten Sektor Perdagangan yang Terdaftar di BEI Tahun 2014-2017). Profita: Komunikasi Ilmiah Akuntansi dan Perpajakan. Vol. 11 No. 3 Desember

11. Mardiasmo. 2009. Perpajakan Edisi Revisi 2009. Yogyakarta: Penerbit Andi.

12. Ni Nyoman Dewi Kristiana dan Ketut Jati. (2014). Pengaruh Karakter Eksekutif, Karakteristik Perusahaan dan Dimensi Tata Kelola Perusahaan yang Baik pada Tax Avoidance. E-jurnal Akuntansi Universitas Udayana. Vol. 6, No. 2

13. Nyoman Budhi Setya Dharma dan Naniek Noviari. (2017). Pengaruh Corporate Social Responsibility dan Capital Intensity Terhadap Tax Avoidance. E-Jurnal Akuntansi Universitas Udayana. Vol. 18, No. 1 Januari

14. Pohan Anwar. (2011). Optimizing Corporate Tax Management, Kajian Perpajakandan Tax Planning Terkini. Edisi I. Jakarta: BumiAksara.

15. Putu Rista Diantari dan IGK Agung Ulupui. (2016). Pengaruh Komite Audit, Proporsi Komisaris Independen, dan Proporsi Kepemilikan Institusional Terhadap Tax Avoidance. E-Jurnal Akuntansi Universitas Udayana. Vol.16, No. 1

16. Rahmi Fadhilah. (2014). Pengaruh Good Corporate Governance Terhadap Tax Avoidance (Studi Empiris pada Perusahaan Manufaktur yang Terdaftar di Bursa Efek Indonesia 2009-2011). Jurnal Akuntansi Universitas Negeri Padang. Vol. 2, No. 1

17. Syeldila \& Niki. (2015). Pengaruh Corporate Governance Terhadap Tax Avoidance: Studi Empiris Pada Perusahaan Manufaktur. JAAI. Vol. 19, No. 2

18. Tommy Kurniasih \& Maria M. Ratna Sari.
(2013). Pengaruh Return On Assets, Leverage, Corporate Governance, Ukuran Perusahaan dan Kompensasi Rugi Fiskal pada Tax Avoidance. BULETIN STUDI EKONOMI. Vol. 18, No. 1 